\title{
philosophical communities of inquiry: the search for and finding of meaning as the basis for developing a sense of responsibility
}

\author{
arie kizel ${ }^{1}$ \\ university of haifa - israel
}

\begin{abstract}
The attempt to define meaning arouses numerous questions, such as whether life can be meaningful without actions devoted to a central purpose or whether the latter guarantee a meaningful life. Communities of inquiry are relevant in this context because they create relationships within and between people and the environment. The more they address relations - social, cognitive, emotional, etc. that tie-in with the children's world even if not in a concrete fashion, the more they enable young people to search for and find meaning. Examining the way in which philosophical communities of inquiry serve as a dialogical space that enables a search for meaning on the personal and collective plane, this article seeks to expand the discussion of how/whether finding meaning on a private or communal level can promote recognition of the existential uniqueness of each individual and the development of a sense of responsibility for him or her. Grounded in the writings of Matthew Lipman, it links his ideas about finding meaning in philosophical communities of inquiry with those of Jean-Paul Sartre, Viktor Frankl, and Emmanuel Levinas, in particular with regard to the association between meaning and responsibility.
\end{abstract}

key words: philosophy with children; philosophical community of inquiry; meaning; responsibility.

\section{comunidades filosóficas de indagación: la búsqueda y el encuentro de significado como la base para desarrollar un sentido de responsabilidad}

resumen

El intento de definir el sentido y significado origina numerosas preguntas, tales como si la vida puede tener sentido sin acciones dirigidas a un propósito central o si este último garantiza una vida con sentido. Las comunidades de indagación son relevantes en este contexto porque crean relaciones entre la gente y el ambiente. Cuanto más se dirigen a las relaciones - sociales, cognitivas, emocionales, etc. que se entrelazan con el mundo de los niños aunque no sea en un modo concreto, tanto más le permiten a los jóvenes buscar y encontrar un sentido. Examinando la manera en que las comunidades filosóficas de indagación sirven como un espacio dialógico que permite una búsqueda del sentido en el plano personal y colectivo, este artículo busca expandir la discusión sobre cómo/si encontrar sentido en un nivel privado o comunitario puede promover el reconocimiento de la singularidad existencial de cada individuo y el desarrollo de un sentido de responsabilidad

\footnotetext{
1 E-mail: ak@akizel.net
} 
philosophical communities of inquiry: the search for and finding of meaning as the basis for developing a sense of responsibility

para él o ella. Basado en los escritos de Matthew Lipman, vincula sus ideas sobre encontrar sentido en las comunidades filosóficas de indagación y aquellas de JeanPaul Sartre, Viktor Frankl, y Emmanuel Levinas, en particular con respecto a la asociación entre sentido y responsabilidad.

palabras clave: filosofía con niños; comunidad filosófica de indagación; sentido; responsabilidad.

\section{comunidades de investigação filosófica: a busca e o encontro de sentido como a base para desenvolver um senso de responsabilidade}

resumo

A tentativa de definir significado o sentido origina numerosas perguntas, tais como se a vida pode ter sentido sem ações dirigidas a um propósito central ou se este último garante uma vida com sentido. As comunidades de investigação são relevantes neste contexto porque criam relações entre as pessoas e o ambiente. Quanto mais se dirigem às relações - sociais, cognitivas, emocionais, etc. - que se entrelaçam com o mundo das crianças ainda que não seja de um modo concreto, mais permitem aos jovens buscar e encontrar um sentido. Examinando a maneira na qual as comunidades de investigação filosófica servem como um espaço dialógico que permite uma busca de sentido no plano social e coletivo, esse artigo busca expandir a discussão sobre como/se encontrar sentido em um nível privado ou comunitário pode promover o reconhecimento da singularidade existencial de cada indivíduo e o desenvolvimento de um senso de responsabilidade para ele ou ela. Baseado nos escritos de Matthew Lipman, vincula suas ideias sobre encontrar sentido nas comunidades de investigação filosófica e àquelas de Jean-Paul Sartre, Viktor Frankl, e Emmanuel Levinas, em particular no que diz respeito à associação entre sentido e responsabilidade.

palavras-chave: filosofia com crianças; comunidade de investigação filosófica; sentido; responsabilidade. 
philosophical communities of inquiry: the search for and finding of meaning as the basis for developing a sense of responsibility

\section{introduction}

By delimiting the space in which students are allowed to voice their ideas, adults tend to ensure that children remain childish, subject to their surroundings and the adult world. If only tacitly, schools are also frequently characterized by a competitive atmosphere and rivalry. Communities of inquiry, in contrast, encourage cooperation and collaboration amongst children in order to support shared learning, promoting the openness necessary for the emergence of (sometimes way out) philosophical ideas.

As recent studies across the globe (LEWIS \& CHANDLEY, 2012; HAYNES \& MURRIS, 2012; CHESTERS, 2012; KIZEL, 2015) have evinced, children think inventively, the questions they ask and work they do in philosophical communities of inquiry honing in them critical, creative, and caring ways of thinking (KOHAN, 2015; GREGORY, 2007). Rather than impairing their learning achievements in traditional fields of knowledge, these forms of learning improve them. This article thus suggests that student philosophical communities of inquiry may also encourage the development of a sense of responsibility in their members - towards themselves, others, and society in general.

The first part associates the searching/finding of meaning with the development of a sense of responsibility in line with Jean-Paul Sartre, Viktor Frankl, and Emmanuel Levinas' thought. The second section analyzes the way in which the process of seeking/finding meaning develops within individuals - in particular in relation to recognizing otherness - in the light of Matthew Lipman's writings.

\section{meaning as fostering a sense of responsibility}

In its everyday workings, the philosophical community of inquiry exhibits numerous affinities with existential thought-in particular meaning, authenticity, and responsibility. Rather than addressing experience solely as a way of searching 
philosophical communities of inquiry: the search for and finding of meaning as the basis for developing a sense of responsibility

for and finding meaning in the Deweyan (1938) sense, however, it views the search for meaning as a process leading to the child's assumption of responsibility for him or herself within the world. In this sense, it closely corresponds to Viktor Frankl's $(1969,1978)$ thought, according to which human beings are spiritual entities whose primary drive is the fierce need to find meaning in life. This impetus, imprinted upon human nature, is perpetual, dynamic, and universal. Human beings differ from other creatures in the world because they possess insight, thus not being condemned to being passive but able to take control of their fate, attitudes, and choices (Fabry, 1988). Viktor Frankl's thought is especially relevant to the contemporary search for meaning because he argues $(1984,2000)$ that human beings strive to know the goal to which they are dedicated to achieving - an aim that gives them a feeling of self-expression and unique selfrealization. This is particularly true of young children taking their first steps along the road of life. According to Viktor Frankl (1984), meaningful lives are purposedriven, people discovering rather than inventing meaning. This theory corresponds to the search for and finding of meaning the philosophical community of inquiry affords, enabling each child to find his or her role and goals in life.

In Viktor Frankl's view, the meaning of life is thus the taking of responsibility for fulfilling one's unique potential-even at a young age. The ability to reach high and live a life imbued with meaning depends on experiencing things that lie beyond ordinary, everyday life. Like Viktor Frankl, Klinger (1977) also relates in distinctive fashion to the concept of the "meaning of life," maintaining that when a person asserts that life has meaning he or she is referring to an experience involving interpersonal relations, a sense of sui generis, and emotionally-laden acts. Those who regard their life as meaningless, in contrast, feel incapable of achieving worthy goals or that those they have set themselves have become insignificant.

At least two of the three ways in which Viktor Frankl asserts that people can find meaning in life are present within philosophical communities of 
inquiry-doing things in life/being active (like volunteering in youth organizations or community centers) and enjoying authentic experiences (like visiting museums or enjoying music). The third - meaning through suffering - is, of course, less relevant to children (it is to be hoped), being intimately linked to Viktor Frankl's Holocaust experience.

The search for and finding of meaning also allows children to uncover their full humanity by enabling them to recognize their uniqueness-i.e., their otherness from those around them and, by the same token, the otherness of others, together with their responsibility towards others. In this sense, the dialogical activity in which philosophical communities of inquiry engage exhibits close affinities with Emmanuel Levinas (2003), at the heart of whose philosophy lie the ethical relations involved in mutual interpersonal understanding-i.e., the relationship between the self and the other. In line with Emmanuel Levinas, we may say that the other demands that the " $\mathrm{I}$ " in the philosophical community of inquiry move beyond the bounds of the self and egocentrism. The search for meaning reveals the self to itself and thereby its otherness from those around it, in the sense not of foreignness but of singularity.

In Humanism of the Other (2003), Emmanuel Levinas contends that the other is created first and foremost as all meaning is created. The search for meaning in the philosophical community of inquiry is thus also a process of the revealing of the other - a process that involves taking responsibility. According to Emmanuel Levinas, this form of responsibility requires commitment, being a destiny rather than a choice. If we return to our notions of evaluation and motivation within the philosophical community of inquiry, we may say that the search for meaning manifests not only the other -i.e., prompts me to take responsibility - but also my own uniqueness (i.e., my otherness), thereby inducing a feeling of responsibility in the other towards me. The community of inquiry thus not only generates meanings but also responsibilities. As Emmanuel Levinas notes, “To be an I ... signifies not to be able to slip away from responsibility" (1963, p. 353). Crossing all the movements of thought, responsibility can never be evaded. 
philosophical communities of inquiry: the search for and finding of meaning as the basis for developing a sense of responsibility

Finally, a link can be drawn between the search for and finding of meaning and developing a sense of responsibility in the Sartrean sense. Jean-Paul Sartre (1966) sought to ground existential philosophy upon ethical foundations via the concepts of responsibility and authenticity, positing that the responsibility for the meaning we attribute to life falls squarely upon our shoulders. This, he argues, forms the basis of the anxiety that constantly plagues humans. On this theory, the meaning we give to life via philosophical communities of inquiry reveals to us what happens in the world, its contexts, and our role-and thus also our responsibility for the things that occur. In other words, the meaning we ascribe to the world is also that which dictates the responsibility we are prepared to accept upon ourselves. Meaning is therefore a means of determining responsibility, philosophical communities of inquiry enabling young people not only to discover the meaning of life but also the purpose and road this bestows opens up for them.

According to Jean-Paul Sartre (1991), human beings give meaning to life by taking part in cultural enterprises, adopting worldviews, developing relationships with others, and above all assuming a self-identity that allows them to find personal meaning in their lives and life in general. A significant part of his phenomenological project is devoted to demonstrating that the need to attribute meaning to life lies at the heart of human existence. In this respect, his view is consistent with Lipman's ideas regarding philosophical communities of inquiry and the search for and finding of meaning they promote not only as part of a pedagogic process of learning designed to encourage rational and creative thought but also towards the creation of a purposeful and meaningful life.

\section{the relevance of the search for meaning and its links}

The search for/finding of meaning is characterized by a distinction between the "meaning of life" and "meaningful life." The pursuit of a meaningful life is a much more elusive philosophical quest than the search for the meaning of life. Meaningful life is one dedicated to things a person finds interesting and significant or attaining goals he or she regards as important (Frankfurt, 1988). Obviously, the attempt to define meaning in this way arouses numerous 
questions, such as whether life can be meaningful without actions devoted to a central purpose or whether the latter guarantee a meaningful life. Communities of inquiry are relevant because they create relationships within and between people and the environment. The more they address relations-social, cognitive, emotional, etc. - that tie-in with the children's world (even if not in a concrete fashion), the more they enable young people to search for and find meaning: "Relevance implies relationship. If something bears no relationship to an individual's own life, then for all practical purposes, it has no meaning for him" (LIPMAN, 1980b, p. 347).

Lipman and Sharp (1992) thus challenge those involved in philosophy with children in particular and educators in general who regard the educational system as irrelevant to open up the existing world to their young charges not only as part of their preparation for life but also as part of their search for meaning in life: "Knowledge and life are not alien to one another, and talking about understanding of the world and the problems that one faces in one's personal life is really important to education. It is essential to education that we show the relevance of that education to the world and to the subjects that study the world" (n.p.). In this framework, Lipman intersects with Dewey's thought (1933/1997), not only viewing relevant experience as driving education (CAM, 1994) but also highlighting the search for relevance as enhancing the search for meaning: "Schools that consider education their mission and purpose are schools that dedicate themselves to helping children find meaning relevant to their lives" (LIPMAN, 1980a, p. 13).

The process of finding meaning through philosophical communities of inquiry is dependent upon schools creating the necessary relevancy in order to challenge children to think about their lives. Lipman thus unsurprisingly argues that

Students and their parents expect that the education provided by schools will be relevant to and applicable to life and the world in which we live. We cannot be expected to develop good judgment if we cannot see the applicability of what we are taught to our daily practice and daily experience. (LIPMAN, 1989, p. 10). 
philosophical communities of inquiry: the search for and finding of meaning as the basis for developing a sense of responsibility

Relevancy allows a three-stage process to occur within the community of inquiry. The first is characterized by the asking of questions, the second by pursuit of the truth, and the third by the search for meaning (LIPMAN, 2003). The search for/finding of meaning takes place within a framework of contexts and relationships, the world around the child in effect supplying him or her with the materials for "making meaning": "The individual has relationships with his work, home, ideals, activities, his past, with the country he lives in, and with humanity in general ... Meanings consist precisely in the relationships that things have to one another ...To understand what something means to us is to grasp the relationship in which it stands to us and to everything else to which it is related" (LIPMAN, 1980b, p. 350).

Within the philosophical community of inquiry adults assist children in distinguishing between the network of relations connecting the various and diverse parts of their lives and find ways to choose between them - if not always harmoniously at least coherently: "Adults can help them understand that meanings are the relationship that things have to us" (LIPMAN, 1980b, p. 347). Lipman holds educators within the philosophical community of inquiry and/or the school as a whole responsible for aiding children understand relations in order to gain as much meaning from them as possible: "If we can help children discover the part-whole relationships in their experience, we can help them find the meaning of those isolated experiences" (LIPMAN, 1980a, p. 67).

The learning and educational experience must be context-rich in order to meet the child's need for meaning that arises from seeing the general picture - a picture that on occasion only the teacher can draw. The latter's primary role is to augment meaning by elucidating the frame of the children's thoughts, thereby enabling them to connect the disparate elements into a conceptual whole: "He can attempt to put their thoughts into some kind of context that will make their thoughts more meaningful to them, for the more comprehensive the setting of an idea is, the richer will that idea be in meaning" (LIPMAN, 1980a, p. 74). 
Rather than a scientific pursuit of the truth, understanding the world demands comprehending uncertainties, inconsistencies, and conflicts in an attempt to see the broad picture, even if the latter is unclear and confused. The philosophical community of inquiry should thus allow for the development of processes focused on the one hand on the "meaning of life" that reflect the experience of existence and explain reality and on the other on the "search for the meaning of life"-i.e., the meaning for which people search and which they fashion and shape in order to give reason and direction to their lives.

The creating of context is not a simple task, Lipman himself not expecting that settings will always be obvious nor, just as importantly, placing great importance on their need to be known ahead of time. He thus attributes significance to other processes that facilitate the search for meaning: "1) discovering alternatives; 2) discovering; impartiality; 2) discovering consistency; 3 ) discovering the feasibility of giving reasons for beliefs; 4) discovering comprehensiveness; 5) discovering situations; 6) discovering part-whole relationships" (LIPMAN, 1980a, p. 68). The meaning forged in philosophical communities of inquiry can be created within both inner and external contexts (such as textbooks): "Since meaning is acquired concomitantly with the perception of the relationship, such meaning is generally spoken of as 'intrinsic'. 'Extrinsic' meaningfulness occurs when means are related to ends in an external or instrumental fashion" (LIPMAN, 1988, p. 9).

The process of finding meaning at the end of the search can also serve as a form of incentive to motivate children to be socially involved. Lipman's work is predicated on the belief that the philosophical community of inquiry can serve to help build young individuals' sense of self and community, enabling them to identify the problems and deficiencies of the society in which they live and propose solutions. Philosophy is thus a motivating force not only for self action but also for social and environmental activism, helping to transform personal competency into social good. It actively searches through questions and finds by gaining answers, both these circles being driven by a teleological form of thinking 
philosophical communities of inquiry: the search for and finding of meaning as the basis for developing a sense of responsibility

that constitutes the platform on the basis of which change can be implemented: "Our contemporary conception of education as inquiry combines both of these aims. Its emphasis is on the process as well as on the product" (LIPMAN, 1997, p. $4)$.

Lipman's paradigm here is the pedagogy of looking for meaning in practical as well as abstract terms. I suggest that this may be called "meaningmaking as an action" or "the action of meaning-making." Within the school framework, this initially takes form of the legitimizing of questions, encouraging students to become active in preparing for their future lives: "Meanings show themselves so intricately involved in our lives that a philosophical analysis of qualitative experience can hardly avoid dealing with them" (LIPMAN, 1956, p. 41). The philosophical community of inquiry space, in which students are exposed to valuable experiences, is one of the most important goals of the educational process: "Once it is acknowledged that, as far as children themselves are concerned, no educational plan will be worthy of the name unless it results in meaningful school and after-school experiences, we can feel some confidence in having arrived at one of the significant criteria for the evaluation of a an educational design" (LIPMAN; SHARP; OSCANYAN, 1980, p. 8).

\section{the individual's search for/finding of meaning}

Philosophical communities of inquiry allow two parallel processes to occur simultaneously on both the conscious and unconscious level: the search for meaning and the finding of meaning. Both these phenomena take place on the personal and collective plane, Lipman (1980a, p. 8) referring to them as the "jigsaw puzzle" model. Both involve two sub-processes - evaluation and motivation - that are essentially values: "Values, after all, are what we want after reflection, analysis, and inquiry, not just what we happen to desire at any particular moment. Such reflection and analysis would have to be philosophical in character" (LIPMAN, 1973, p. 3). Values being definable in terms of the role they play, evaluation and motivation can be tested with regard to how they apply to things, actions, and actors. Thus, for example, a member of a philosophical community of 
inquiry may know how he or she defines justice and how to distinguish between just and unjust acts.

Evaluation consists of taking a stand with regard to something, either for or against on either an internal (intrapersonal) or external (interpersonal) plane. The members of philosophical communities of inquiry assess the questions they raise, the answers they give, and the questions and answers of others. This is not necessarily a verbal process, evaluation frequently deriving from feelings and emotions. At the same time, or immediately afterwards, they share the results of this process with the group, their peers thus directly affecting the assessment process, often in a quite radical fashion.

Collective inquiry thus tends to produce two effects-evaluation as a process and values themselves (i.e., a stance taken towards subjects, objects, people, actions, etc.). Evaluation leading to the adoption of values within a philosophical community of inquiry forms the basis for one of the most important processes in which the community engages-namely, the search for meaning. Hereby, the participants develop conceptual systems that enable them to find meaning. At this stage, answers are given to the questions that have arisen within the community, primarily on an ethical plane. As Lipman notes, "It is, thus, by doing philosophical inquiry generally that children prepare themselves to do ethical inquiry, and by doing ethical inquiry with regard to instrumental and procedural consideration they prepare themselves to give serious attention to substantive values" (LIPMAN, 1997, p. 3).

Values also serving as an incentive, they form part of the motivation mechanism. Thus, for example, a value can prompt the member of a philosophical community of inquiry to do something he or she regards as right. In other words, during the search for meaning participants do not merely evaluate by means of a process but are also roused to act by mobilizing values.

On occasion, the members of philosophical communities of inquiry implicitly examine whether conflicts exist between what they think and belief and what others think. If they do, they frequently disclose them in order to discover 
philosophical communities of inquiry: the search for and finding of meaning as the basis for developing a sense of responsibility

whether other members encounter the same mismatch. This divulgence is then likely to start another round of acknowledgements, generating more questions that stimulate further values amongst the members and the group as a whole. In other words, at the search-for-meaning stage, values function like two balls thrown into the air in a philosophical juggling game. During this phase, positive and negative values are constantly tested, their content depending on the subject under discussion.

The two roles of evaluation and motivation take shape in the practical thought aroused by the philosophical community of inquiry. As Lipman stated, "Wherever experience is shared in a fashion that enables the participants to discover the meaning of their participation, there is a community" (1988, p. 119). The community of inquiry functions as a space that enables a "search for better understanding and justified beliefs through collaborative reasoning and dialogue are at the centre" (HAYNES; MURRIS, 2012, p. 4). Or, as Splitter and Sharp contend, it is "at once immanent and transcendent: it provides a framework which pervades the everyday life of its participants and it serves as an ideal to strive for" (LIPMAN, 1995, p. 17-18).

During the search for meaning, the participants in philosophical communities of inquiry construct a type of "hierarchy of values." Examining the range of actions open to them, they check with themselves (and then possibly with others) what they think they would do in any given situation. Here, the community provides them with a space - or philosophical laboratory - in which to test positive and negative values and motives. Within this philosophical discussion, which to the observer may seem incoherent, a series of factors are at play - the various objectives, cognitive inputs, and values the members bring with them from diverse cultural backgrounds (KIZEL, 2016). As Lipman notes, philosophical discussions are thus "precisely the proper medium for putting things in perspective, getting a sense of proportion, and achieving some kind of insight into the direction of one's life" (LIPMAN, 1973, p. 27). 
In many cases, during the community debates the participants can forge what I call a "hybrid route" - i.e., a choice between positive values and negative actions or negative values and positive actions from the hierarchical order their home, religion, culture, or nationality dictates. During this selection process, they check the function their will plays as a mechanism organizing the relationships between people. The will thus mediates between values and motivations or evaluation and action, settling value conflicts. In this way, the philosophical community of inquiry enables children-sometimes within a single session - to simultaneously execute a rather complex series of moves that encourage critical and creative thought. As Walter Omar Kohan observes, "Philosophy as experience of thinking is unique, unrepeatable, and nonnegotiable. Philosophical thinking cannot be turned into scientific knowledge, cannot be normalized, uniformized, or standardized. In philosophy, no one can think for another" (LIPMAN, 2014, p. 37). Or as Lipman asserts: "A justification for doing philosophy with children is their need to find meaning in their own life" (LIPMAN, 1978, p. 8).

Regarding the question of the search for/finding of meaning to be one of the key aspects of philosophical inquiry, Lipman devoted himself to it throughout his writing project: "I am now convinced that philosophy can and should be a part of the entire length of a child's education ... If we really want children to find their education meaningful, we'll devise a suitable philosophical component" (LIPMAN, 1976, p. 27). This belief derives from his conviction during his extended writing that the search for meaning lays at the heart of the philosophical enterprise: "You need to ask the child to clarify, explain exactly what their question means so everyone in the group can understand. Philosophy is about meaning. Science is about truth, Philosophy is about meaning" (LIPMAN, 2004, p. $44)$.

In Philosophy Goes to School, Lipman identifies meaning as integral to philosophy with children, noting that they ask questions because they want answers. As elsewhere in his works, he links the skills necessary for good reading, understanding, choice, and taking a position and asking questions about it within 
philosophical communities of inquiry: the search for and finding of meaning as the basis for developing a sense of responsibility

the community with a preoccupation with words as meaning-makers, arguing that all these combine together to create meaning: "Whenever anyone looks for meanings in things or in one's perception of things and fails to find them, he or she comes to think of the whole enterprise as futile, because 'there are no meanings'. But if meanings were relationships, the quest would not be futile at all. ... To understand the meanings in a work of literature is to explore the relationships to be found among the words and between the words and oneself. On the other hand, to express meanings one must find connections or relationships that will do that job. This is why the creation of works of art, such as poems, has a way of making existence meaningful" (LIPMAN, 1988, p. 137).

In Philosophy in the Classroom, he refers in similar terms to the association between meaning and relationships - the meaning created in the relationships between the participants in the community of inquiry and the subject being discussed: "... meaning emerges from the perception of part-whole relationships as well as of means-ends relationships" (LIPMAN, 1980a, p. 8). In other words, meaning is created as in a game or game-relations in precisely the same way as a word is understood from a sentence or an episode from the context of the film as a whole. Meaning is thus procedural.

At the same time, "Even if philosophy does not provide ultimate meanings, it conveys to the child that the quest is feasible and worthwhile" (LIPMAN, 1978, p. 8). The search for meaning organizes a child's unique traits and self-image, not only helping them develop skills and experience in using them but also creating meaning - first personal and then collective. These understandings allow children to ask questions about the text, the relevance of questions and answers about life, and the possibility of changing it and making a difference in society.

From this perspective, the participants in philosophical communities of inquiry create what I call the "meaning of the moment" and the "horizon of meaning." Some also regard the search for meaning as a form of selftranscendence - the possibility of moving beyond the here and now to the forging 
of a vision (customarily characterized by the will to make a difference for the good) and recognition of something bigger than oneself.

Each child engages in his or her own search for meaning. Although all share generic features, such as a cognitive system for evaluation and motivation and a set of values that reflect social conventions, they all go through different stages of action and/or understanding. Lipman contends that the human wealth within the philosophical community of inquiry establishes the uniqueness of each member, awareness of this distinctiveness forming part of the enhancing of personal philosophical skills and self-empowerment: “The meaning to children of their own experience may be, in part, its exclusiveness - the realization that what is impossible for others is indeed possible for them, and them alone" (LIPMAN, 1980b, p. 294).

The evaluation and motivation process in the search for meaning also promotes tolerance and acceptance of diverse evaluative and motivational styles. Hereby, the members of the philosophical community of inquiry develop their capacity to be aware, even if they do not always recognize or cope well with variety and divergence from their own traits. This stage thus enables them to foster an empathy and appreciation of the singular nature of these processes in others as they come to realize just how distinct they are: "The discussion promotes children's awareness of one another's personalities, interests, values, beliefs and biases" (LIPMAN, 1973, p. 12).

Lipman regards the multiformity of cognitive styles, beliefs, and views that exist in the classroom as advantageous, philosophy with children constituting fertile ground for enriching the communal space: "Philosophy for children can be expected to flourish in a heterogeneous classroom where students speak out of a variety of life styles and experiences, where different beliefs as to what is important are explicit, and where a plurality of thinking styles [exists] ... The variety of thinking styles in the classroom, coupled with a variety of backgrounds, values and life experiences, can contribute significantly to the creation of a community of inquiry" (LIPMAN; SHARP, 1978, p. 86-87). 
philosophical communities of inquiry: the search for and finding of meaning as the basis for developing a sense of responsibility

\section{conclusion}

This article has examined two central elements of philosophical communities of inquiry - the search for meaning and the finding of meaning. These processes are essentially value-charged, being closely linked with evaluation and motivation - i.e., action. According to Matthew Lipman, one of the key functions of philosophical communities of inquiry is to enable young people to gain insights into themselves, those around them, and social life via a series of value processes made possible by relevance, contexts, and relationships prompted by dialogical pedagogy. The search for and finding of meaning of Lipman can be associated with the principles of Viktor Frankl, Emmanuel Levinas, and Jean-Paul Sartre's thought in relation to fundamental concepts such as the discovery of individual uniqueness, responsibility for the other, and the acceptance of responsibility. Humanistic philosophical communities of inquiry that study all sorts of texts and champion personal freedom and choice foster growth and an ethics based on the way in which human beings attribute meaning to life and the assumption of responsibility for the self, others, and humanity as a whole.

\section{references}

CAM, P. Dewey, Lipman, and the tradition of reflective education. In M. Taylor, H. Schreier, \& P. Ghiraldelli, Jr. (eds.). Pragmatism, education and children. Amsterdam, Holland: Editions Rodopi B.V. 1994, pp. 163-181.

CHESTERS, S. D. The Socratic classroom: Reflective thinking through collaborative inquiry. Rotterdam, Holland: Sense, 2012.

Dewey, J. How we think. Mineola, NY: Dover, 1933/1997.

Dewey, J. (1938). Experience and education. New York, NY: Macmillan.

Frankfurt, H. G. The importance of what we care about: Philosophical essays. Cambridge, UK: Cambridge University Press, 1988.

Fabry, J. Guideposts to meaning: Discovering what really matters. Oakland, CA: New Harbinger, 1988.

Frankl, V. E. The will to meaning: Foundations and applications of logotherapy. New York, NY: World Pub. Co, 1969.

Frankl, V. E. The unheard cry for meaning: Psychotherapy and humanism. New York, NY: Simon and Schuster, 1978.

Frankl, V. E. Man's search for meaning. New York, NY: Washington Square Press, 1984. Frankl, V. E. Man's search for ultimate meaning. New York, NY: MJF Books, 2000. Gregory, M. A framework for facilitating classroom dialogue. Teaching Philosophy, 30(1), 59-84, 2007. 
Haynes, J., \& Murris, K. Picturebooks, pedagogy and philosophy. New York, NY: Routledge, 2012.

Kizel, A. "'Life goes on even if there's a gravestone': Philosophy with Children and Adolescents on Virtual Memorial Sites". Childhood and Philosophy, Vol. 10, Number 20, 421-443, 2015.

Kizel, A. (2016). Enabling identity: The challenge of presenting the silenced voices of repressed groups in philosophic communities of inquiry. Journal of Philosophy in Schools, 3(1), 16-39.

Klinger, E. (1977). Meaning and void. Minneapolis, MN: University of Minnesota Press.

Kohan, W. O. (2014). Philosophy and childhood: Critical perspectives and affirmative practices.

New York, NY: Palgrave Macmillan.

Kohan, W. O. (2015). Childhood, education and philosophy: New ideas for an old relationship.

New York, NY: Routledge.

Levinas, E. (1963). The trace of the other: http://jst.ufl.edu/pdf/dragan2001.pdf (accessed 28/8/16).

Levinas, E. (2003). Humanism of the other. Chicago: University of Illinois Press.

Lewis, L., \& Chandley, N. (Eds.) (2012). Philosophy for children through the secondary curriculum. London, UK: Continuum.

Lipman, M. (1956). The physical thing in aesthetic experience. Journal of Aesthetics and Art Criticism, 15(1), 36-46.

Lipman, M. (1973). Philosophy for children. Montclair, NJ: Institute for the Advancement of Philosophy for Children.

Lipman, M. (1976). Metaphilosophy, 7(1), 17-39.

Lipman, M. (1978). Growing up with philosophy. Philadelphia, PA: Temple University Press.

Lipman, M. (1980a). Philosophy in the classroom. Philadelphia, PA: Temple University Press.

Lipman, M. (1980b). How and why. Montclair, NJ: Institute for the Advancement of Philosophy for Children.

Lipman, M. (1988). Philosophy goes to school. Philadelphia, PA: Temple University Press. Lipman M. (1989). Misconceptions in teaching for critical thinking. Montclair, NJ: Resource Publication Series 2 No. 3.

Lipman M. (1997). In their best interest? Analytic Teaching, 17(1), 1-4.

Lipman, M. (2003). Thinking in education. New York, NY: Cambridge University Press.

Lipman, M. (2004). Simple gifts: Interview with Matthew Lipman.

Lipman, M and Sharp, A. M. (1978). Some Educational Presuppositions of Philosophy for Children. Oxford review of education, 4(1), 85-90.

Lipman, M., \& Sharp, A. M. (1992). Interview with Matthew Lipman and Ann Margaret Sharp.

Lipman, M., Sharp, A. M., \& Oscanyan, F. (1980). Philosophy in the classroom. Philadelphia, PA: Temple University Press.

Sartre, J. P. (1966). Being and nothingness. London, UK: Methuen.

Sartre, J. P. (1991). Critique of dialectical reason. London, UK: Verso.

Splitter, L., \& Sharp, A. M. (1995). Teaching for better thinking: The classroom community of enquiry. Melbourne, Australia: Acer. 